\title{
Mineralization, Alteration Assemblages and Stable Isotopes of the Intermediate-Sulfidation Epithermal Strauss Deposit, Drake Goldfield, North-Eastern NSW, Australia ${ }^{\dagger}$
}

\author{
Emmanuel Madayag ${ }^{1, *}$, Ian Graham ${ }^{1}$, Hongyan Quan ${ }^{1}$, Rohan Worland ${ }^{2}$, Lewis Adler ${ }^{3}$ and Christian Dietz ${ }^{4}$ \\ 1 School of Biological, Earth and Environmental Sciences, UNSW Sydney, Kensington, NSW 2052, Australia; \\ i.graham@unsw.edu.au (I.M.); hongyan.quan@unsw.edu.au (H.Q.) \\ 2 White Rock Minerals Ltd., 12 Anderson Street, West Ballarat, VIC 3350, Australia; \\ rworland@whiterockminerals.com.au \\ 3 Bioanalytical Mass Spectrometry Facility, UNSW Sydney, Kensington, NSW 2052, Australia; \\ 1.adler@unsw.edu.au \\ 4 Central Science Laboratory, University of Tasmania, Hobart, TAS 7001, Australia; \\ christian.dietz@utas.edu.au \\ * Correspondence: elmadayag@gmail.com; Tel.: +61-4-3211-9609 \\ + Presented at the 2nd International Electronic Conference on Mineral Science, 1-15 March 2021; \\ Available online: https://iecms2021.sciforum.net/.
}

Citation: Madayag, E.; Graham, I.; Quan, H.; Worland, R.; Adler, L.;

Dietz, C. Mineralization, Alteration Assemblages and Stable Isotopes of the Intermediate-Sulfidation Epithermal Strauss Deposit, Drake Goldfield, North-Eastern NSW, Australia. Environ. Sci. Proc. 2021, 6, 27. https://doi.org/10.3390/ iecms2021-09350

Academic Editor: Paul Sylvester

Published: 25 February 2021

Publisher's Note: MDPI stays neutral with regard to jurisdictional claims in published maps and institutional affiliations.

Copyright: (๑) 2021 by the authors. Licensee MDPI, Basel, Switzerland. This article is an open access article distributed under the terms and conditions of the Creative Commons Attribution (CC BY) license (http://creativecommons.org/licenses/by/4.0/).

\begin{abstract}
The intermediate-sulfidation epithermal Strauss deposit is part of the Drake Goldfield of north-eastern NSW, Australia. The mineralization is gold dominant with minor silver and significant zinc, copper and lead. Strauss has a combined total resource of $2.66 \mathrm{Mt} @ 1.5 \mathrm{~g} / \mathrm{T}$ Au and 1.9 $\mathrm{g} / \mathrm{T}$ Ag. Petrographic analysis has shown the deposit to be hosted by varying layers of dacitic ash flow tuffs and a cross-cutting lamprophyre dyke though previous authors classified some of the tuffs as intrusive andesites. Mineralization mainly occurs in the form of vein stockworks of three main orientations. Structural analysis indicates that these resulted from two fault system events and one conjugate fault system. Petrographic and SEM analysis shows that there are two different mineralization styles, a pyrite dominant and chalcopyrite dominant assemblage, with three main mineralization events. Correlation analysis for the assay data indicates that $\mathrm{Au}$ has a strong relationship with $\mathrm{Ag}$ and a moderate correlation with $\mathrm{Pb}$. XRD analysis indicates widespread argillic-phyllic and propylitic alteration. Silver tellurides have been found as late-stage grains associated with the chalcopyrite mineralization assemblage. Sr shows a significant depletion due to the intense and pervasive alteration at Strauss. The carbon and oxygen isotopes of the vein carbonates suggests that the carbon from the late-stage carbonates was derived from a magmatic source with a significant input of low temperature meteoric water, while the sulfur isotopes indicate a magmatic sulfur source.
\end{abstract}

Keywords: Drake Goldfield; Strauss; structurally-controlled; intermediate sulfidation; epithermal deposit; gold; alteration

\section{Introduction}

The Drake Goldfield, also known as the Mount Carrington Group, is located close to the New South Wales and Queensland border, $\sim 5 \mathrm{~km}$ north of Drake village, $\sim 750 \mathrm{~km}$ north of Sydney and $\sim 240 \mathrm{~km}$ south of Brisbane (Figure 1). Epithermal mineralization is widespread in this area, with numerous low to intermediate sulfidation epithermal $\mathrm{Au}$ and Ag deposits including Strauss, Kylo, Red Rock, Lady Hampden, Silver King, White Rock, and White Rock North [1] (Figure 2). These deposits lie within the Drake Volcanics, a NW-SE trending sequence of Late Permian volcanics and volcaniclastics spanning an area of $60 \times 20 \mathrm{~km}$. The White Rock silver deposit was first discovered in 1886 and its geology first described by Andrews [2]. The Drake Goldfield has since been further 
explored and multiple deposits of differing geology have been discovered and mined. Despite this, research on the Drake deposits is minimal, and only very limited research has been conducted on one of the main economic deposits, Strauss, with a summary description last published in the 1980s [3]. Furthermore, the only study of significant detail on the Drake Goldfield as a whole was that of Perkins [4] focusing on the Red Rock deposit, one of the less significant deposits in the region. Work by White Rock Minerals Limited has recently suggested that economic mineralization within the Drake Volcanics is associated with the 'Drake Quiet Zone' (DQZ), interpreted as a collapsed volcanic caldera centered around Mount Carrington.

The Drake Goldfield has been mined for precious metals, particularly $\mathrm{Au}$ and $\mathrm{Ag}$, since the late 1800s [5,6], with the most recent activity by Mt. Carrington Mines from 1988 to 1990, producing approximately $23 \mathrm{Koz}$ of $\mathrm{Au}$ and $435 \mathrm{Koz}$ of Ag [7]. Recent exploration has indicated that the Drake Goldfield still contains approximately $352 \mathrm{Koz}$ of $\mathrm{Au}$ and 23.3 Moz of Ag [7]. The Strauss deposit is characterized by its vein-rich, structurally-controlled mineralization (Figure 3). Based on current exploration and analysis, the Strauss deposit contains the largest gold resource in the Mount Carrington Group, with a total resource of $2.66 \mathrm{Mt} @ 1.5 \mathrm{~g} / \mathrm{T} \mathrm{Au}$ and $1.9 \mathrm{~g} / \mathrm{T} \mathrm{Ag}$.

This paper will focus on the unique, vein-rich, structurally-controlled Strauss deposit, and aims to identify the relationship between the volcanic units and Au mineralization as well as develop an understanding of the genesis and alteration evolution of the deposit. A greater understanding of the Strauss deposit and knowledge of the controls on the economic mineralization will be used for proposed future mining and exploration both within the Drake Goldfield, as well as for epithermal systems in the New England Orogen and in general.

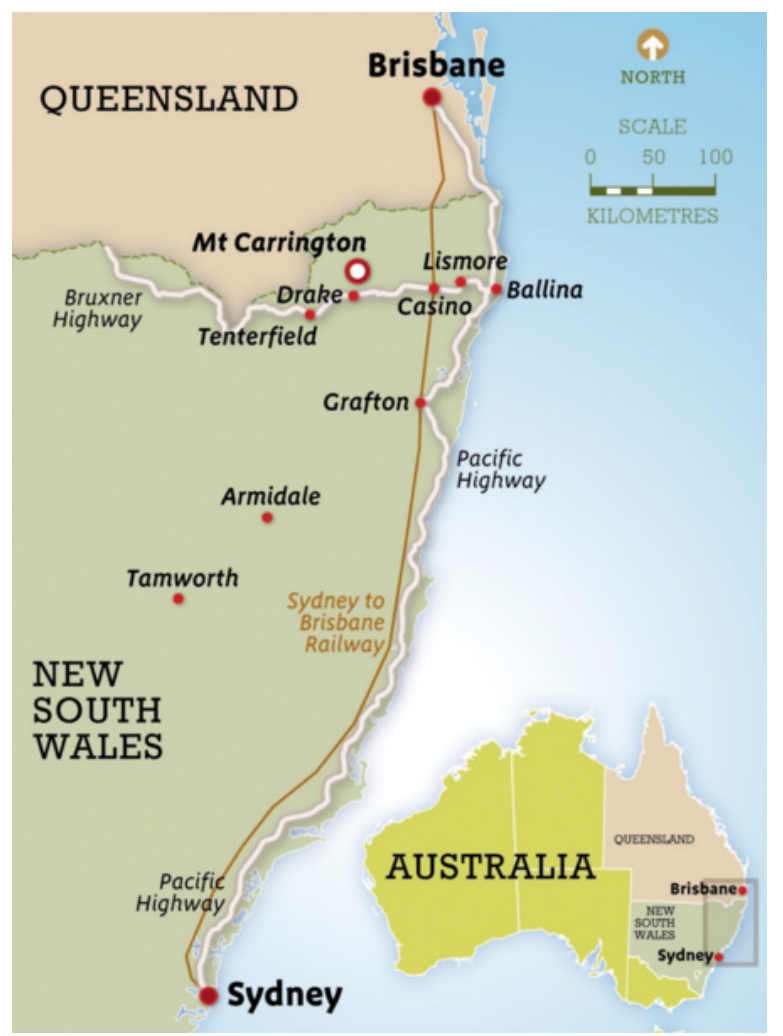

Figure 1. Simplified map showing location of the Mount Carrington Group in relation to Sydney, Brisbane, Drake, and other major towns in New South Wales [5]. 

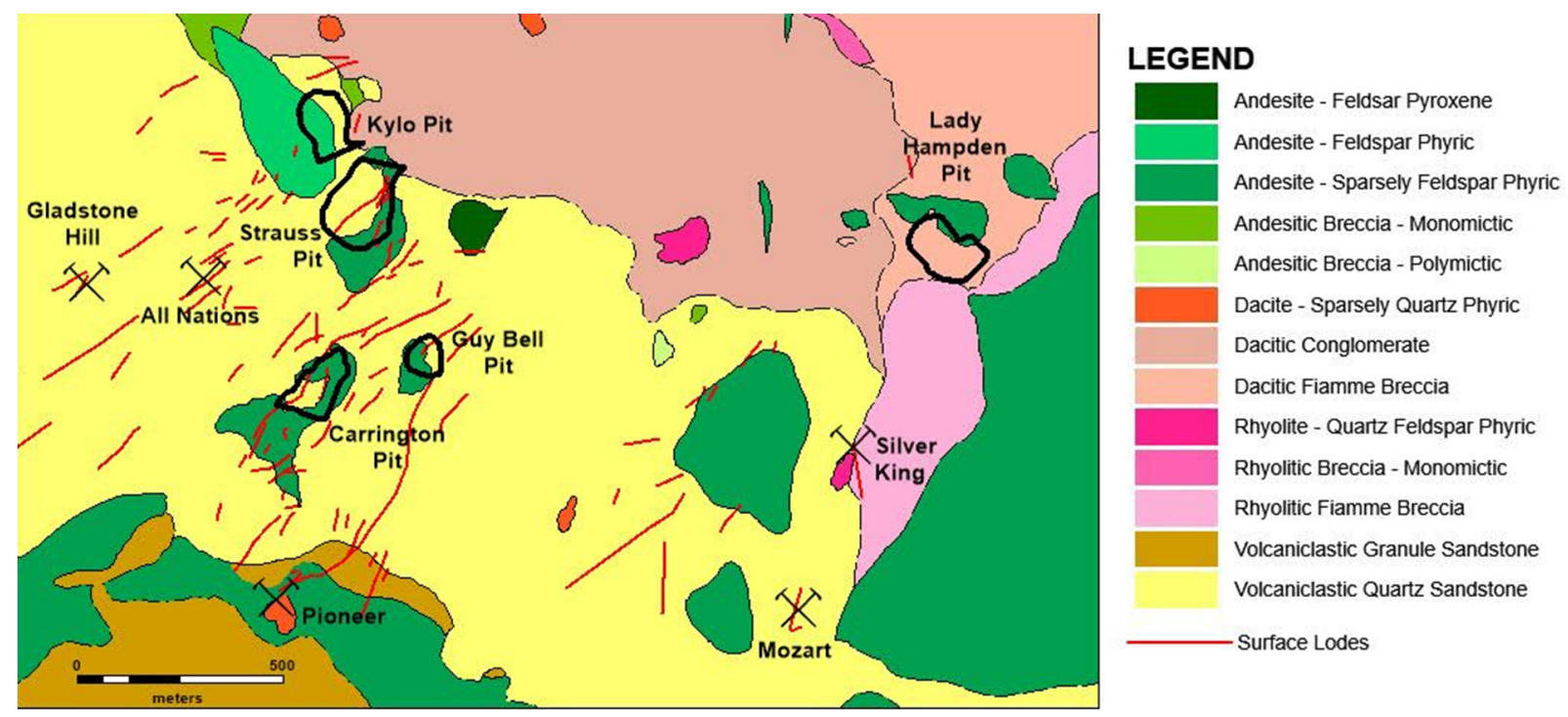

Figure 2. Simplified local geological map of the Mount Carrington group from [1]. Note: Red Rock, White Rock and White Rock North are not shown on this map.

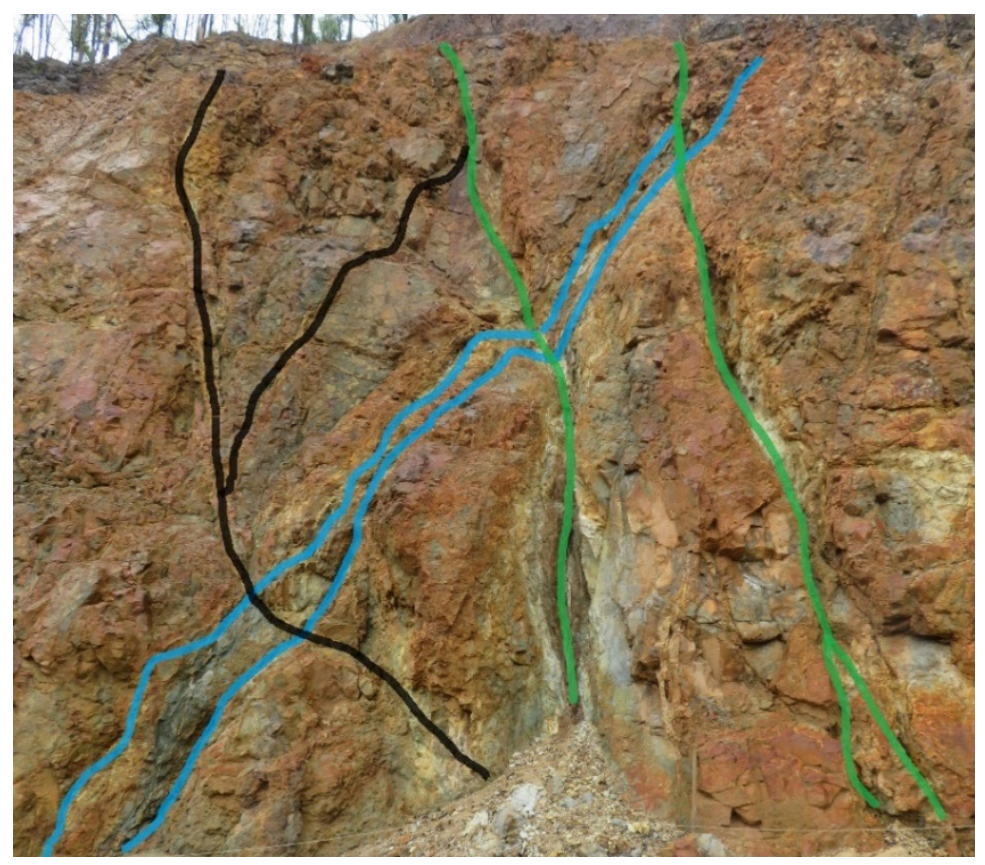

Figure 3. Major conjugate shear and vein structures in the south wall of the Strauss open-cut. All are intensely altered and mineralized. S1-blue, S2-green, conjugate vein-black.

\section{Materials and Methods}

Samples for this project were selected for detailed analysis from three diamond drill cores and the old Strauss open-cut in order to examine a 'strongly mineralized' drill core with relatively abundant high-grade Au, a relatively 'poorly mineralized' drill core with relatively minimal Au mineralization, and a 'stratigraphic' drill core that best showed the overall stratigraphy through the Strauss deposit and the previously mined open-cut. Based on assay data from White Rock Minerals Ltd., and advice from White Rock Minerals geologists, SRDD016 was chosen as the 'strongly mineralized' core, SRDD015 was chosen as the 'poorly mineralized' core, and SRDD021 was chosen as the 'stratigraphic' core. Hand samples, polished mounts and thin sections, and pulps were taken from these cores for geochemical and petrographic analysis based on $\mathrm{Au}, \mathrm{Ag}, \mathrm{Cu}, \mathrm{Pb}$, and $\mathrm{Zn}$ levels from assay data and at regular depth intervals in order to examine the mineralogy, alteration, 
and any relationships between the two. Hand samples and pulps were chosen if assay data indicated $\mathrm{Au}$ greater than $0.5 \mathrm{ppm}$, and/or $\mathrm{Cu}$ above 5000 ppm, Ag above 40 ppm, $\mathrm{Pb}$ over $1000 \mathrm{ppm}$, or Zn over 1500 ppm, or they were within one meter of economic mineralization. Unmineralized sections were sampled every five meters in depth. Sampling of the Strauss open-cut walls and floors was done in order to accurately map the lithology and alteration and mineralization focused on the numerous quartz and sulfide veins and the different rock units. Samples from the open-cut were also made into polished mounts, thin-sections and analyzed.

X-ray diffraction (XRD) analysis was carried-out using the PANalytical Empyrean II $X R D$ in to study the alteration assemblages. Data was then converted using ConvX and analyzed in Xplot32 ${ }^{\mathrm{TM}}$. Operational procedures followed that of Burkett, et al. [8]. Portable $X$-ray fluorescence (pXRF) analysis was performed at UNSW using the Olympus Innov-X Vanta $\mathrm{pXRF}$, to analyze pulp samples taken from the drill holes and the open cut, following the methodology developed by Lau [9].

Three carbonate veins were chosen from Strauss to conduct carbon and oxygen isotope analysis. These carbonates were collected as powders through the use of a tungsten tipped micro-drill and placed into small sample holders before being ground with an agate mortar and pestle to ensure homogeneity. Analysis was conducted in the Bioanalytical Mass Spectrometry Facility, Mark Wainwright Analytical Centre at the University of New South Wales, Sydney. This procedure and methodology followed Markowska et al. [10]. Stable sulfur isotope analysis was conducted using the flash combustion isotope ratio mass spectrometry at the Central Science Laboratory, University of Tasmania, Australia using a varioPYRO cube coupled to Isoprime100 mass spectrometer. The $\mathrm{SO}_{2}$ produced during combustion is trapped and measured against a reference gas in a mass spectrometer, and stable isotope abundance deviances are reported as $\delta$ values in comparison to conventional standards in parts per million. The $\delta^{34} S$ values are reported relative to the Canyon Diablo Troilite. IAEA-S-1, IAEA-S-2, and IAEA-S-3, IAEA-SO5, NBS 123 and NBS 127 were measured for instrument calibration to ensure accuracy.

\section{Results and Discussion}

\subsection{Lithology, Alteration, and Mineralisation}

\subsubsection{Lithology}

The host rock lithology primarily consists of varying andesitic to dacitic vitric crystal tuffs. Minor mineralization occurs within the host rock as cross-cutting veins; however, most of the mineralization is hosted within structures such as shear zones and major crosscutting veins. Intense and pervasive alteration is present throughout the Strauss open-cut, as well as in all the drill holes SRDD015, SRDD016 and SRDD021, with most samples showing silicification, chloritization, illitization and pyritization. Based on Corbett and Leach [11] and Simmons [12], major intermediate argillic and minor phyllic and propylitic alteration assemblages have been identified within the deposit through thin-section and XRD analysis.

\subsubsection{Alteration and Veining}

Argillic alteration occurs within Strauss as the assemblage illite, kaolinite, chlorite, pyrite and siderite. In this assemblage, there is intense and pervasive illitization of plagioclase clasts, volcanic ash clasts, and volcanic glassy fragments, followed by chlorite replacement of vitric clasts with phenocrysts of plagioclase and volcanic quartz (Figure 4B,C).

Propylitic alteration is rare at Strauss, occurring primarily as calcite and albite in association with an intrusive lamprophyre in drill core, a large mafic dyke in the open cut, and on contacts of ash bands in drill cores. Phyllic alteration assemblages of illite-muscovite, carbonate and albite also commonly occurs. 
Multiple generations of quartz are visible as laminated veins, cross-cutting veins, sinuous veins, and open-space veins. Quartz also occurs as replacement of feldspars and infilling former vesicles (Figure 4A,D).
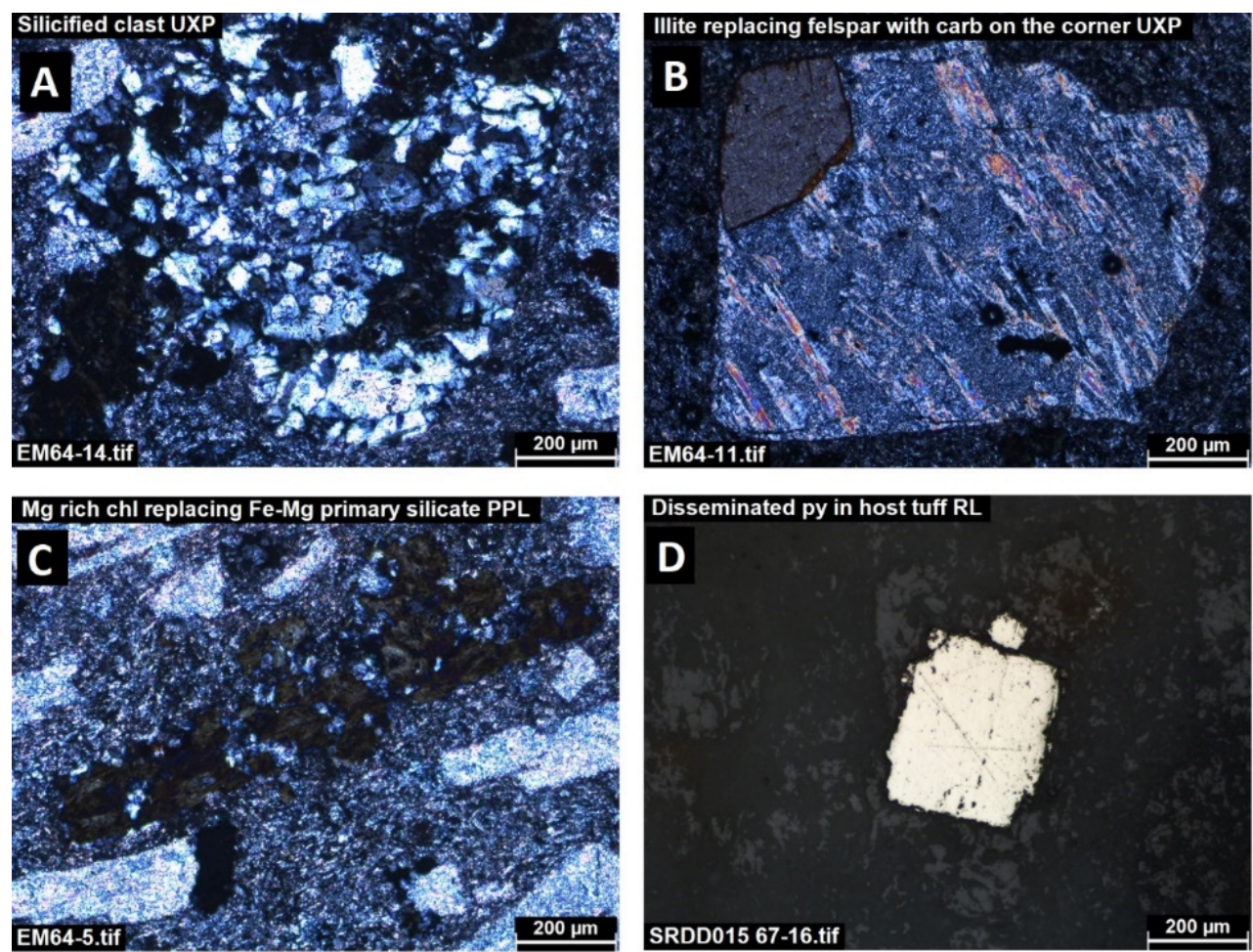

Figure 4. Examples of argillic alteration assemblages from Strauss: (A) Silicified clast, UXP; (B) illite replacement of feldspar overprinted by later carbonate, UXP; (C) magnesium-rich chlorite replacement of an iron-magnesium silicate, PPL; (D) euhedral grain of disseminated pyrite in host tuff, RL.

\subsubsection{Mineralization}

Based on petrographic analysis, mineralization at Strauss is polymetallic, and occurs in at least three deposit-wide mineralization events. The first stage is observed as disseminated anhedral inclusion-rich pyrite (Py1) (Figure 5A) and pyritized clasts rimmed by chalcopyrite (Cpy1), sphalerite (Sph1), and galena (Gn1) in the host rock. The second main phase consists of euhedral to subhedral pyrite (Py2) grains and grain aggregates (Figure 5B). It is found rimming and overprinting Py1 and is commonly infilled by chalcopyrite (Cpy2), sphalerite (Sph2), and galena (Gn2) (Figure 5C). Py2 aggregates are commonly intergrown with silicates, indicating an intimate association with argillic alteration (Figure 5B). Ductile deformation is also present in Gn2, indicating ductile deformation post-deposition (Figure 5E). Exsolution lamellae of chalcopyrite (Cpy2) also occurs within sphalerite (Sph2) (Figure 5D). The third event is late stage, and is predominantly chalcopyrite (Cpy3) rimming and co-crystallized with sphalerite (Sph3) and galena (Gn3) (Figure 5F). It is often rimmed by covellite, chalcocite, and occasionally bornite (Figure 5G). Native gold also occurs as grains and micro-veinlets in Cpy2 and Sph3 (Figure 5I). Tennantite group minerals and polybasite are also associated with this event (Figure 5H). The mineralization is noticeably structurally-controlled, with mineralized and unmineralized structures following two main orientations, striking on average at $5^{\circ}$ and $25^{\circ}$ and one minor orientation striking at $325^{\circ}$. 

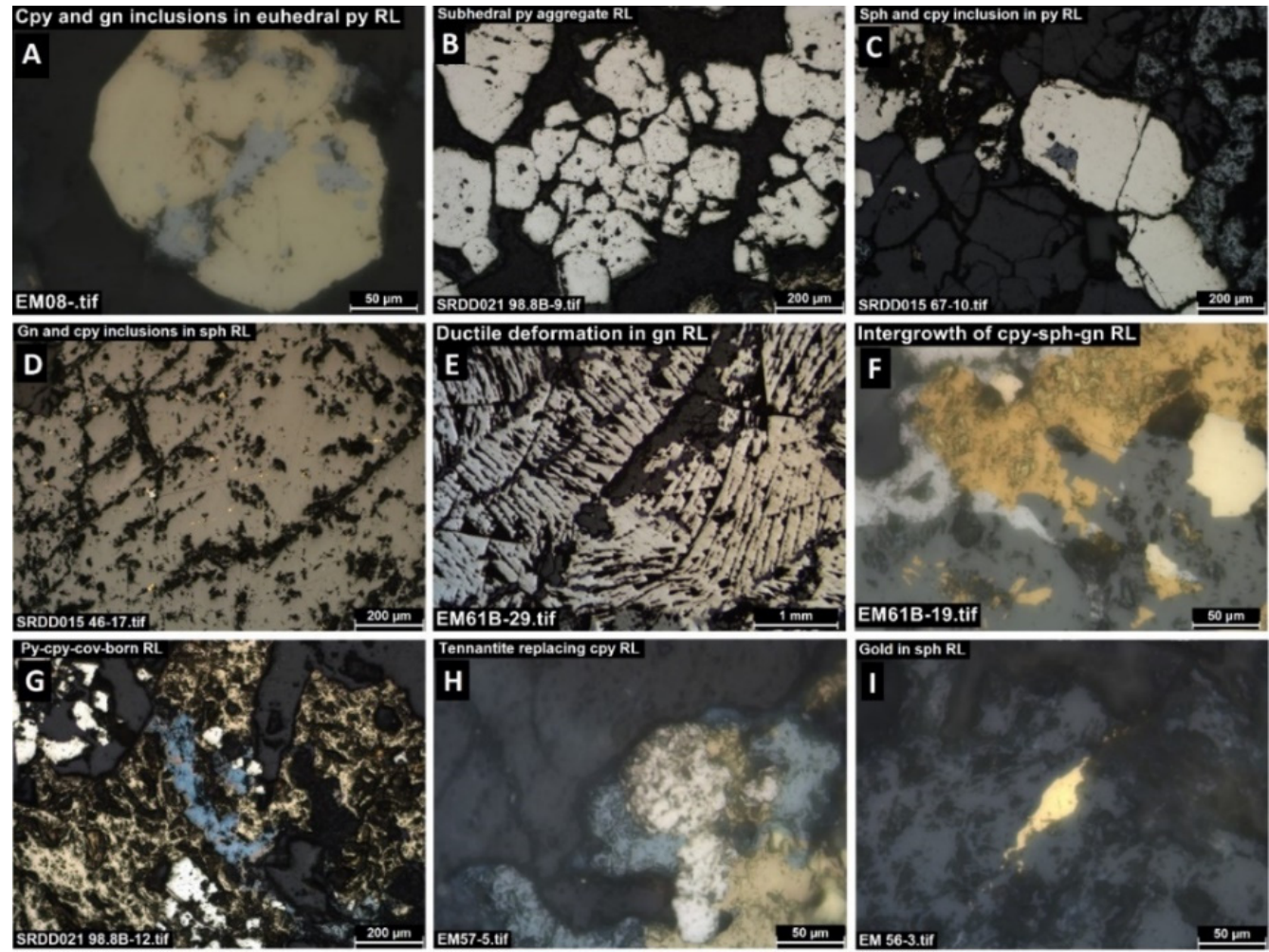

Figure 5. Reflected light images of ore minerals from the Strauss deposit: (A) Euhedral inclusionrich pyrite (Py1) grain with chalcopyrite and galena inclusions; (B) subhedral pyrite (Py2) grain aggregate in silicates; (C) chalcopyrite (Cpy2) and galena (Gn2) inclusions in pyrite (Py2) grain; (D) galena (Gn2) and chalcopyrite (Cpy2) inclusions in sphalerite (Sph2); (E) ductile deformation of galena (Gn2); (F) intergrown chalcopyrite (Cpy3), sphalerite (Sph3) and galena (Gn3); (G) Covellite and bornite rimming chalcopyrite (Cpy3); (H) tennantite replacement of chalcopyrite (Cpy3); (I) native gold in sphalerite (Sph3).

\section{2. $p X R F$}

Due to the intense alteration throughout Strauss, $\mathrm{Ti}, \mathrm{Zr}, \mathrm{Nb}$, and $\mathrm{Y}$ were used as immobile elements to classify the host rock lithologies as andesitic to dacitic. The main tuff units in the Strauss open cut have been classified as andesitic, with Zr:Ti ratios ranging from 0.02-0.05. In drill core, higher units tend to be andesitic, with ratios of 0.02 , before turning dacitic with depth, with ratios averaging at 0.12 . Detailed petrographic analysis further identified these to be various tuffs.

\subsection{Assay Data Analysis}

Correlation between $\mathrm{Au}$ and other elements at Strauss is weakly to moderately positive. $\mathrm{Au}$ vs. $\mathrm{Pb}$ and $\mathrm{Zn}$ shares the weakest relationship in all drill cores, while $\mathrm{Au}$ vs. $\mathrm{Cu}$ and Au vs. Ag have the strongest relationships. All $p$ values are The Spearman Rank correlation coefficients of $\mathrm{Au}$ vs. $\mathrm{Pb}+\mathrm{Zn}$, $\mathrm{Au}$ vs. $\mathrm{Cu}, \mathrm{Au}$ vs. $\mathrm{Ag}$, and $\mathrm{Au}$ vs. As within each drill core are listed in Table 1 below together with their $p$ value.

Table 1. Spearman rank correlation matrix by drill core from Strauss.

\begin{tabular}{cccc}
\hline & $\begin{array}{c}\text { SRDD015 }(n=164) \\
\text { Poorly Mineralized }\end{array}$ & $\begin{array}{c}\text { SRDD016 }(\boldsymbol{n}=124) \\
\text { Strongly Mineralized }\end{array}$ & $\begin{array}{c}\text { SRDD021 }(\boldsymbol{n}=114) \\
\text { Moderately Mineralized }\end{array}$ \\
\hline $\mathrm{Au}$ vs. $\mathrm{Pb}+\mathrm{Zn}$ & $\mathrm{R}_{2}=0.47, p=0$ & $\mathrm{R}_{2}=0.28, p=0$ & $\mathrm{R}_{2}=0.25, p=0$ \\
$\mathrm{Au}$ vs. $\mathrm{Cu}$ & $\mathrm{R}_{2}=0.65, p=0$ & $\mathrm{R}_{2}=0.39, p=0$ & $\mathrm{R}_{2}=0.66, p=0$ \\
$\mathrm{Au}$ vs. $\mathrm{Ag}$ & $\mathrm{R}_{2}=0.71, p=0$ & $\mathrm{R}_{2}=0.54, p=0$ & $\mathrm{R}_{2}=0.44, p=0$ \\
$\mathrm{Au}$ vs. $\mathrm{As}$ & $\mathrm{R}_{2}=0.55, p=0$ & $\mathrm{R}_{2}=0.36, p=0$ & $\mathrm{R}_{2}=0.62, p=0$ \\
\hline
\end{tabular}




\subsection{Stable Isotopes}

Through the use of $\mathrm{pXRD}$, magnesite, dolomite, and calcite were identified at Strauss. Results of the stable isotope analyses are listed in Table $2 . \delta^{13} \mathrm{CPDB}_{\mathrm{PD}}$ in Strauss carbonates ranges from -11.46 to $-5.15 \%$ while $\delta^{18}$ Osmow ranges from 8.82 to $19.03 \%$. The $\delta^{13} C_{\text {PDB }}$ is very close to the mantle value range, whilst the $\delta^{18} \mathrm{Osmow}$ value indicates significant influence from low-temperature meteoric fluids $[13,14]$. The very small range of $\delta^{34} \mathrm{~S} C D T$ within the sulfides in Strauss indicates that they were formed under stable physical and chemical conditions and derived from a relatively homogenous source [15]. The sulfur in Strauss is interpreted to be of magmatic origin, or has been leached from the host volcanic sequence, as the $\delta^{34} S_{\mathrm{CDT}}$ value is near to $0 \%$ o $[14,16]$.

Table 2. Carbon, oxygen, and sulfur isotope compositions for Strauss.

\begin{tabular}{|c|c|c|c|c|c|}
\hline Sample ID & Depth (m) & Mineralogy & $\delta^{13}$ СРDв (\%o) & $\delta^{18}$ Osmow (\%o) & $\delta^{34} \mathrm{~S}_{\mathrm{CDT}}(\% \mathrm{\%})$ \\
\hline SRDD001-165.75 & 165.75 & Calcite & -9.07 & 8.93 & \\
\hline SRDD002-156.6 & 156.6 & Calcite & -9.48 & 16.34 & \\
\hline SRDD002-176.5 & 176.5 & Calcite & -8.46 & 13.53 & \\
\hline SRDD002-205.7-205.75A & 205.7-205.75 & Dolomite & -5.15 & 13.19 & \\
\hline SRDD002-205.7-205.75B & 205.7-205.75 & Magnesite & -5.37 & 12.97 & \\
\hline SRDD002-212.6 & 212.6 & Magnesite and Calcite & -7.43 & 19.03 & \\
\hline SRDD002-227.7 & 227.7 & Magnesite and Calcite & -7.84 & 17.18 & \\
\hline SRDD002-236.6-237 & $236.6-237$ & Calcite & -7.46 & 17.60 & \\
\hline SRDD002-242.6 & 242.6 & Calcite & -11.46 & 7.80 & \\
\hline SRDD010-111.9 & 111.9 & Magnesite & -8.72 & 11.73 & \\
\hline SRDD010-113.3 & 113.3 & Siderite and Magnesite & -10.44 & 17.67 & \\
\hline SRDD015-68.7 & 68.7 & Dolomite & -8.59 & 8.82 & \\
\hline SRDD015-106.5 & 106.5 & Magnesite and Calcite & -6.36 & 17.23 & \\
\hline SRDD010-50.5 & 50.5 & Sphalerite & & & -2.23 \\
\hline SRDD020-10A & 10 & Pyrite and Sphalerite & & & -2.39 \\
\hline SRDD020-10B & 10 & Sphalerite & & & -3.09 \\
\hline SRDD020-12.6 & 12.6 & Sphalerite & & & -2.39 \\
\hline SRDD020-14.8 & 14.8 & Pyrite & & & -2.70 \\
\hline SRDD020-38.15 & 38.15 & Sphalerite & & & -4.15 \\
\hline SRDD020-23.2 & $23.2-23.3$ & Sphalerite & & & -1.80 \\
\hline SRDD021-72.6 & 72.6 & Sphalerite & & & -2.41 \\
\hline EM56 & - & Sphalerite & & & -0.53 \\
\hline EM57 & - & Sphalerite & & & -1.45 \\
\hline EM61 & - & Sphalerite & & & -2.09 \\
\hline EM62 & - & Sphalerite & & & -3.45 \\
\hline EM68 & - & Pyrite & & & -2.68 \\
\hline
\end{tabular}

\section{Conclusions}

The abundance of intermediate-sulfidation state sulfides, such as pyrite, chalcopyrite, sphalerite, and galena, and the presence of tennantite group minerals, tetrahedrite, polybasite, and iron-poor sphalerite, indicates that Strauss is an intermediate sulfidation epithermal deposit. The deposit is hosted by andesitic to dacitic crystal vitric tuffs. This is consistent with the stable $\mathrm{C}$ and $\mathrm{O}$ isotope analyses, which also indicated a significant influence from low temperature meteoric alteration $[17,18]$. Strauss has at least three mineralization events and multiple alteration events. Argillic alteration and Au mineralization are connected to each other. Stable isotope analysis indicates a magmatic source for sulfur.

Author Contributions: E.M. wrote the manuscript, collected the samples, undertook some of the analyses and interpreted the data. I.G. provided technical input and supervised the project. H.Q. cosupervised the project, ran the XRD analysis and provided technical input. R.W. provided technical input and arranged access to the deposit. C.D. ran and helped interpret the stable isotope analyses. L.A. ran the IRMS and assisted in the analysis of the carbon, oxygen and sulfur isotope compositions. All authors have read and agreed to the published version of the manuscript. 
Institutional Review Board Statement: Not applicable.

Informed Consent Statement: Not applicable.

Data Availability Statement: Data supporting the reported results is available upon request from the UNSW School of BEES or Emmanuel Madayag.

Acknowledgments: The authors would like to acknowledge White Rock Minerals Ltd. for providing support for this research. We would also like to acknowledge the facilities and the scientific and technical assistance of Microscopy Australia at the Electron Microscope Unit (EMU) within the Mark Wainwright Analytical Centre (MWAC) at UNSW Sydney.

Conflicts of Interest: The authors declare no conflicts of interest.

\section{References}

1. Cumming, G. New Geological Constraints for the Drake Volcanics, Drake Area, Northern NSW; Internal Report for White Rock Minerals Limited; White Rock Minerals Limited: Ballarat, VIC, Australia, 2011.

2. Andrews, E.C. Report on the Drake Gold and Copper Field; William Applegate Gullick: Sydney, NSA, Australia, 1908.

3. Bottomer, L. Epithermal silver-gold mineralization in the Drake area, north eastern New South Wales. Aust. J. Earth Sci. 1986, 33, 457-473.

4. Perkins, C. The Red Rock deposit: A late Permian submarine epithermal precious metal system in Northeastern New South Wales. In Pacific Rim 87. International Congress on the Geology, Structure, Mineralization and Economics of Pacific Rim; Elsevier Science: Amsterdam, The Netherlands, 1987; pp. 895-898.

5. White Rock Minerals. Mt Carrington Project: Overview, Geological Setting, Resources, Development, Exploration Gold and Silver, and Exploration Copper. Available online: https:/www.whiterockminerals.com.au/mt-carrington-overview (accessed on 10 March 2020).

6. Craighead, G.; Gordon, M. White Rock Minerals (WRM): Low Cost Gold/Silver Start-Up Opportunity, Sydney. Breakaway Investment Group; White Rock Minerals Limited: Ballarat, VIC, Australia, 2016.

7. White Rock Minerals Limited. Exceptional Updated Gold Pre-Feasibility Results. ASX Announcement 19th August 2020; White Rock Minerals Limited: Ballarat, VIC, Australia, 2020.

8. Burkett, D.A.; Graham, I.T.; Ward, C.R. The application of portable X-ray diffraction to quantitative mineralogical analysis of hydrothermal systems. Can. Mineral. 2015, 53, 429-454.

9. Lau, F. Geochemical Discrimination of the Chemostratigraphy and Alteration Assemblages of the Kulumadau Epithermal Gold Deposit, Woodlark Island, Papua New Guinea. Bachelor's Honours Thesis, University of New South Wales, Kensington, NSW, Australia, 2012.

10. Markowska, M.; Cuthbert, M.O.; Baker, A.; Treble, P.C.; Andersen, M.S.; Adler, L.; Griffiths, A.; Frisia, S. Modern speleothem oxygen isotope hydroclimate records in water-limited SE Australia. Geochim. Cosmochim. Acta 2020, 270, 431-448, doi:10.1016/j.gca.2019.12.007.

11. Corbett, G.J.; Leach, T.M. Southwest Pacific Rim Gold-Copper Systems: Structure, Alteration, and Mineralization. In Society of Economic Geologists Special Publication 6; The Economic Geology Publishing Company (PUBCO); New Haven, Conneticut, USA, 1997.

12. Simmons, S.F.; White, N.C.; John, D.A.; Hedenquist, J.W.; Thompson, J.F.H.; Goldfarb, R.J.; Richards, J.P. Geological Characteristics of Epithermal Precious and Base Metal Deposits. One Hundredth Anniv. Vol. 2005, 485-522, doi:10.5382/av100.16.

13. Ohmoto, H.; Rye, R.; Barnes, H. Geochemistry of Hydrothermal Ore Deposits; Wiley: New York, NY, USA, 1979 ; Volume 67.

14. Shanks, W.P. Stable Isotope Geochemistry of Mineral Deposits. Treatise Geochem. 2014, 13, 59-85, doi:10.1016/b978-0-08-0959757.01103-7.

15. Xiong, Y.; Zhai, Y. Oxygen isotope studies of epithermal systems: A review. Chin. J. Geochem. 1992, 11, 329-343, doi:10.1007/bf02869064..

16. Herbert, H.; Smith, J. Sulfur isotopes and origin of some sulfide deposits, New England, Australia. Miner. Depos. 1978, 13, 5163, doi:10.1007/bf00202907.

17. White, N.; Hendequist, J. Epithermal gold deposits: Styles, characteristics, and exploration. SEG Newsp. 1995, 1, 9-13.

18. Wang, L.; Qin, K.-Z.; Song, G.-X.; Li, G.-M. A review of intermediate sulfidation epithermal deposits and subclassification. Ore Geol. Rev. 2019, 107, 434-456, doi:10.1016/j.oregeorev.2019.02.023. 